\title{
The Quality of Bus Rapid Transit (BRT) Shelter Services of Mangkang-Penggaron Route in CBD Semarang
}

\author{
Putri Mahardhini', Mardwi Rahdriawan²
}

\begin{abstract}
The Government of Semarang have sought to develop a mass transportation system using the concept of Bus Rapid Transit (BRT) in Mangkang-Penggaron corridor. In order to effectively facilitate the movement of city dwellers, the BRT system required the provision of functioning shelters along the corridor. There is a need to optimize the function of the shelters including the integration to other modes of transportation and to the activities of the Central Business District (CBD), ensuring optimum performance of the whole BRT system. This study determined and evaluated the quality of BRT shelter services in Semarang based on user perception. The study employed analysis regarding the fulfillment of criteria for quality of services including waiting time, convenience, service reliability, distance, and BRT shelter clerk services. The analysis processes concluded that the current BRT shelter services were in fact less than ideal. The study found lack of maintenance and the need for improvement of services at rush hour.
\end{abstract}

Keywords: evaluation, quality of services, and bus shelter

\section{PENDAHULUAN}

Kualitas pelayanan merupakan isu sentral saat ini, semua organisasi bersaing pada tingkatan yang kompetitif sehingga mendorong para profesional untuk lebih memperhatikan nilai tambah pelayanan sebagai sumber aktual untuk mencapai tingkat pelayanan yang maksimal. Adanya fokus pelayanan sistem transportasi perkotaan yang menjadi satu hal penting dalam perbaikan kinerja dan peningkatan mutu pelayanan publik dalam sistem perkotaan untuk memenuhi kebutuhan masyarakat sehingga dapat menjadi alat komunikasi antara pelanggan dengan penyedia pelayanan dalam upaya meningkatkan pelayanan, untuk mengukur kinerja pelayanan, serta menjadi alat monitoring dan evaluasi kinerja pelayanan publik dalam sistem transportasi perkotaan.

Permasalahan transportasi sangat terkait dengan tumbuhnya aktivitas komersial di wilayah perkotaan yang berdampak pada bangkitnya pergerakan lalu lintas yang semakin hari semakin bertambah, sedangkan kapasitas jalan tidak mengalami pertambahan khususnya dari sisi lebar dan kuantitasnya, akibatnya angkutan umum yang berkembang pada akhirnya adalah berbasis bus dan mobil. Angkutan publik selalu diarahkan menuju ke pusat perekonomian yang biasanya berada di wilayah perkotaan sehingga jalan-jalan di kota menjadi macet dan tidak lancar. Salah satu inovasi pemerintah Kota Semarang untuk mengatasi permasalahan transportasi yang

\footnotetext{
${ }^{1}$ Putri Mahardhini adalah Mahasiswa Jurusan Perencanaan Wilayah dan Kota, Universitas Diponegoro, Semarang, Jawa Tengah

${ }^{2}$ Mardwi Rahdriawan adalah Dosen Jurusan Perencanaan Wilayah dan Kota, Universitas Diponegoro, Semarang, Jawa Tengah
} 
semakin kompleks adalah dengan mengembangkan public transport priority. Pola operasionalnya dapat menggandeng pihak swasta.

Kebijakan dari pemerintah untuk mengembangkan sistem angkutan umum massal dengan konsep BRT (Bus Rapid Transit) diharapkan akan mampu menjadi alternatif solusi dalam mengurangi kemacetan lalu lintas di Semarang. Pemberian prioritas angkutan umum massal biasanya dilakukan di kota-kota besar karena akan membawa penumpang dalam jumlah yang besar, sehingga pengurangan waktu tempuh yang kecil akan membawa keuntungan yang besar (Tamin, 2000). Sistem angkutan umum massal yang dibuat oleh pemerintah kota Semarang bekerjasama dengan Dishub Kota Semarang, pihak swasta PT. Trans Semarang, nantinya harus menjadi angkutan umum yang ideal agar diminati oleh masyarakat Kota Semarang.

Implementasi BRT dilakukan pertama kalinya pada Koridor Mangkang-Penggaron yang dipandang sebagai koridor tersibuk di Kota Semarang, dimana sepanjang koridor ini adalah kawasan komersial, perkantoran, pemerintahan, jasa dan pusat-pusat aktivitas, serta perekonomian masyarakat. Pembangunan koridor Mangkang-Penggaron dimulai dengan pembangunan halte-halte BRT di sepanjang koridor dan juga dilengkapi dengan fasilitasfasilitas layanannya. Jenis halte BRT adalah halte yang didesain khusus untuk menyampaikan identitas yang dapat membedakan dari pelayanan transportasi umum lainnya, mencerminkan jenis pelayanan yang baik dan terintegrasi dengan lingkungan sekitar (Ditjen Perhubungan Darat, 2006). Sampai pada bulan Mei 2010 hanya satu koridor saja yang telah beroperasi untuk melayani pergerakan aktivitas masyarakat Kota Semarang, dimana data menunjukkan bahwa jumlah pengguna moda angkutan BRT meningkat dari bulan ke bulan.

TABEL 1

PERKEMBANGAN JUMLAH PENGGUNA TRANS SEMARANG KORIDOR MANGKANG-PENGGARON

\begin{tabular}{ll}
\hline Bulan Pengoperasian & Jumlah Total Pengguna (pnp) \\
\hline 12 November 2009 & 49.420 \\
\hline Desember 2009 & 89.926 \\
\hline Januari 2010 & 92.446 \\
\hline Februari 2010 & 75.396 \\
\hline Maret 2010 & 85.893 \\
\hline April 2010 & 80.171 \\
\hline 21 Mei 2010 & 70.414 \\
\hline Sumber: PT. Trans Semarang, 2010
\end{tabular}

Kualitas pelayanan halte masih dirasa kurang, padahal kebutuhan akan halte yang aman, nyaman, dan mudah digunakan sangat diperlukan dalam pengembangan moda transportasi BRT karena halte BRT merupakan salah satu faktor yang membedakan layanan BRT dengan layanan moda transportasi lainnya. Dalam studi ini difokuskan di pusat aktivitas masyarakat CBD (Central Bussiness District) tepatnya BWK I Koridor Mangkang-Penggaron Kota Semarang. Wilayah ini terpilih menjadi area penelitian karena merupakan wilayah yang sering dikunjungi masyarakat Kota Semarang dan wilayah tersibuk sebagai pusat aktivitas masyarakat. Selain itu, trayek angkutan umum (bus kota dan angkutan kota) yang melewati wilayah ini mengangkut penumpang menuju ke tempat-tempat bisnis, perkantoran, dan perdagangan (supermarket, mall, pasar, dan toko). 
Halte BRT yang sedang dikembangkan di BWK I (pusat Kota Semarang) dengan koridor Mangkang-Penggaron sepanjang 13 kilometer terdapat 12 halte yang ternyata belum mampu menyelesaikan masalah sarana dan prasarana transportasi bagi Kota Semarang. Sarana dan prasarana pendukung sistem BRT tersebut belum dapat berjalan dengan baik dan ideal. Berawal dari keberadaan halte ini, maka perlu adanya studi untuk mengevaluasi kualitas pelayanan halte BRT tersebut dengan pertanyaan penelitian: Bagaimana kualitas pelayanan halte BRT BWK I (pusat kota) Koridor Mangkang-Penggaron?

\section{METODOLOGI PENELITIAN}

Metode pendekatan yang yang digunakan dalam penelitian ini adalah mix-method dengan menggunakan pendekatan kuantitatif-kualitatif. Data dihimpun melalui kuesioner, wawancara, dan observasi yang disiapkan sebelumnya. Sifat kuantitatif deskriptif dapat dilihat pada analisis skoring/pembobotan kriteria-kriteria penentu kualitas pelayanan halte BRT seperti waktu tunggu BRT, sarana prasarana pendukung keberadaan halte BRT (kemudahan pencapaian, kemudahan pelayanan, kelengkapan halte BRT), jarak antar halte BRT, ketepatan perpindahan rute dan ketepatan pelayanan halte, serta mutu pelayanan yang terdiri dari kemudahan dan kesederhanaan penggunaan sistem BRT, kenyamanan menggunakan BRT, estetika halte untuk kemudian dilakukan kajian lebih lanjut mengenai kualitas pelayanan halte BRT di koridor Mangkang-Penggaron menggunakan pendekatan kualitatif.

\section{KAJIAN KUALITAS PELAYANAN HALTE BRT}

Beberapa kunci penting untuk meraih suksesnya implementasi kebijakan penggunaan angkutan umum massal berbasis bus ini antara lain, bahwa rute BRT harus terintegrasi dengan moda lain. Dalam penetapan jaringan trayek busway, selain memperhatikan ketersediaan ruang milik jalan yang cukup memadai, diperlukan pula suatu persyaratan bahwa jaringan harus terintegrasi dengan moda lain untuk kemudahan transfer, seperti dengan moda kereta api, bus kota, mikrolet/MPU dan juga taksi. Keterpaduan lain yang tidak kalah pentingnya adalah terhadap moda pengumpan (feeder) dan juga fasilitas pejalan kaki serta fasilitas parkir untuk park and ride. Rute BRT harus terintegrasi dengan pengembangan tata ruang, artinya rute BRT yang termasuk didalamnya halte/stasion sebagai titik transfer dengan pengembangan tata ruang. Perencanaan rute busway yang baik akan menarik penumpang dari berbagai jenis ruang kegiatan.

Selain itu, jalur khusus BRT harus tidak terganggu oleh lalu lintas lain. Jalur khusus busway harus diupayakan tidak tercampur oleh arus lalu lintas yang lain dengan tanpa gangguan. Pemasangan separator, fasilitas prioritas hingga membuat persimpangan tidak sebidang akan membuat kapasitas dari busway menjadi lebih tinggi. Tidak kalah pentingnya desain BRT serta fasilitasnya harus menarik penumpang untuk mendapatkan kapasitas yang optimal perlu dipertimbangkan pemakaian bus gandeng dengan desain dan fasilitas yang menarik. Pentingnya image dari suatu pelayanan akan lebih banyak menarik orang untuk menggunakan fasilitas yang ada. Busway di dunia seperti Bogota, Kolombia, dan Sao Paolo, Brasil merupakan sistem pengoperasian dan pelayanan fungsi halte yang optimal yang dirujuk busway DKI, Yogyakarta, dan kota-kota lainnya dimana mampu mengangkut 30.000 penumpang per jam per arah. 
Menurut Vuchic (1981.275) halte (bus station) adalah area atau bangunan di luar Jalan (offstreet) sebagai tempat berhenti bagi angkutan umum. Halte biasanya dibangun pada lokasi yang merupakan tempat tarikan atau bangkitan kegiatan serta tempat pertemuan beberapa rute/trayek angkutan umum dimana banyak penumpang yang beralih moda (transfer). Selain itu, lokasi halte harus mempunyai aksesibilitas yang baik dengan lingkungan sekitamya. Halte pada Bus Jalur Khusus adalah halte dengan desain khusus untuk menyampaikan identitas yang dapat membedakan dari pelayanan transportasi umum lainnya, mencerminkan jenis pelayanan prima dan terintegrasi dengan lingkungan sekitar, perlu adanya keterlibatan masyarakat/ organisasi profesional, sehingga memperhatikan keserasian dengan lingkungan, berfungsi sebagai ornamen kota, memperhatikan aksesibilitas bagi penyandang cacat, dan lokasi halte didasarkan pada sistem pembagian zona.

\section{Spesifikasi Teknis Halte}

Dalam draft pedoman teknis, angkutan bis kota dengan sistem jalur khusus yang dikeluarkan oleh Ditjen Perhubungan Darat, ada beberapa spesifikasi teknis dalam penentuan halte, spesifikasi teknis tersebut adalah:

- Panjang halte dipengaruhi oleh jenis kendaraan yang digunakan sebagai Bus Jalur Khusus. Apabila menggunakan bus besar maka panjang halte yang dianjurkan 18 meter. Bila menggunakan bus sedang maka panjang halte yang dianjurkan Bus Jalur Khusus 10 meter.

- Jarak standar antar halte sekitar 500 meter, namun dapat berkisar antara 300 hingga 1000 meter tergantung kondisi setempat.

- Kapasitas halte 1350-2250 pnp/jam.

- Kisaran ruang untuk satu orang penumpang 0,7 $\mathrm{m}^{2}$ dan fasilitas utama $15 \mathrm{~m}^{2}$.

- Lebar halte biasanya bervariasi antara 3-5 meter.

- Standar ketinggian permukaan lantai halte sama dengan ketinggian pintu masuk kendaraan Bus Jalur Khusus, hal ini untuk mempermudah penumpang naik dan turun kendaraan. Pada kendaraan Bus Jalur Khusus yang menggunakan bus sedang, tinggi permukaan lantai halte adalah $70 \mathrm{~cm}$ dari permukaan jalan. Pada kendaraan Bus Jalur Khusus yang menggunakan bus besar, tinggi permukaan lantai halte adalah $110 \mathrm{~cm}$ dari permukaan jalan.

TABEL 2

JARAK ANTAR HALTE

\begin{tabular}{llll}
\hline No. & Tata Guna Lahan & Lokasi & $\begin{array}{l}\text { Jarak Tempat } \\
\text { Henti (meter) }\end{array}$ \\
\hline 1 & $\begin{array}{l}\text { Pusat kegiatan sangat padat } \\
\text { (pasar, pertokoan) }\end{array}$ & CBD Kota & $200-300$ \\
\hline 2 & $\begin{array}{l}\text { Padat: perkantoran, } \\
\text { sekolah, jasa }\end{array}$ & Kota & $300-400$ \\
\hline 3 & Perumahan & Kota & $300-400$ \\
\hline 4 & $\begin{array}{l}\text { Campuran padat: } \\
\text { perumahan, sekolah, jasa }\end{array}$ & Pinggiran & $300-500$ \\
\hline 5 & $\begin{array}{l}\text { Campuran jarang: } \\
\text { perumahan, ladang, sawah, } \\
\text { tanah kosong }\end{array}$ & Pinggiran & $500-1000$ \\
\hline
\end{tabular}

Sumber: Ditjen Perhubungan Darat, 2006 


\section{Fasilitas Tempat Pemberhentian Kendaraan Penumpang Umum}

Fasilitas minimal yang harus dimiliki oleh suatu halte untuk dapat memberikan pelayanan yang memadai terhadap penumpang yaitu fasilitas utama untuk halte antara lain identitas halte berupa nama atau nomor, rambu petunjuk, papan informasi trayek, lampu penerangan, tempat duduk. Sedangkan fasilitas untuk TPB terdiri dari rambu petunjuk, papan informasi trayek, identifikasi TPB berupa nama atau nomor. Untuk fasilitas tambahan berupa telepon umum, tempat sampah, pagar, papan iklan/pengumuman. Pada persimpangan, penempatan fasilitas tambahan ini tidak boleh mengganggu ruang bebas pandang. Fasilitas lain yang harus diperhatikan dalam pengoperasian halte BRT adalah ramp disediakan untuk melayani orang yang memiliki keterbatasan fisik, serta berguna bagi penumpang yang mempunyai bawaaan berupa kereta bayi, koper beroda, dan bawan-bawaan berat lainnya. Orang-orang yang memiliki keterbatasan fisik yang masih bisa menggunakan tangga akan lebih memilih ramp jika tersedia dan lebih nyaman. Ramp seharusnya tidak memilki kemiringan lebih besar dari $8,3 \%$, kemiringan yang biasanya digunakan adalah $4 \%$ sampai $6,25 \%$.

\section{Tata Letak Halte Terhadap Ruang Lalu Lintas}

1. Jarak maksimal terhadap fasilitas penyeberangan pejalan kaki adalah 100 meter

2. Jarak minimal halte dari persimpangan adalah 50 meter atau tergantung dari panjang antrian

3. Jarak minimal dari suatu gedung (seperti : rumah sakit, tempat ibadah) yang membutuhkan ketenangan adalah 100 meter

4. Peletakan, di persimpangan menganut sistem campuran yaitu antara sesudah persimpangan (farside) dan sebelum persimpangan (nearside)

Kriteria kondisi pelayanan ideal yang akan dilihat oleh pengguna dan diamati oleh peneliti dalam operasionalnya (Transit Capacity and Quality of Service Manual): 1) Kebersihan dan Penampilan: penampilan fisik dari eksterior, kebersihan lantai dan bangku, kebersihan dinding dari coretan, dan kondisi fisik lingkungan lainnya yang bisa dilihat secara kasat mata serta bersifat tangible; 2) Informasi Pelanggan: penandaan yang benar serta bisa dikenali, papan display jadwal kedatangan dan keterlambatan BRT, peta-peta yang mudah dimengerti pengguna, pemberian informasi yang akurat dan bisa dimengerti; 3) Fasilitas yang disediakan halte untuk memberikan pelayanan: kondisi pengontrol cuaca, kemudahan penggunaan fasilitas, keberadaan pintu otomatis, keberadaan penjualan tiket, penerangan, serta fasilitas lainnya yang tersedia; 4) Operator: keberadaan petugas berseragam, petugas keamanan, dan petugas kebersihan dan penjual tiket. Perlu diperhatikan juga kerapian, kedisiplinan, keramahan, dan respon petugas dalam memberikan pelayanan kepada penumpang.

Berdasarkan uraian teoritis dari beberapa ahli di atas, maka dapat diperoleh beberapa kriteria dalam menentukan lokasi halte. Kriteria tersebut meliputi beberapa aspek yaitu penumpang, angkutan umum, lingkungan, dan tata guna lahan. Idealnya, keberadaan suatu halte harus dapat memenuhi kebutuhan sebagai berikut:

1. Jarak antar halte minimal berkisar antara 500 meter

2. Tata letak halte berada pada median jalan

3. Lokasi halte difokuskan untuk jumlah penumpang pada tata guna lahan yang berpotensi membangkitkan jumlah penumpang yang cukup tinggi

4. Halte terletak dekat jalur pejalan kaki dan fasilitas pejalan kaki

5. Diarahkan dekat dengan pusat kegiatan atau permukiman

6. Tidak mengganggu kelancaran arus lalu lintas

7. Menjamin keselamatan bagi pengguna angkutan penumpang umum

8. Menjamin kepastian keselamatan untuk menaikkan dan/atau menurunkan penumpang; 
9. Memudahkan penumpang dalam melakukan perpindahan moda angkutan umum

10. Pada persimpangan, penempatan fasilitas tambahan tidak boleh mengganggu ruang bebas pandang

11. Ruang untuk satu orang penumpang berkisar $0,7 \mathrm{~m}^{2}$, sedangkan untuk fasilitas utama berkisar $15 \mathrm{~m}^{2}$

Daya tampung halte tergantung dari jumlah rute/trayek, headway pada saat jam puncak untuk masing-masing rute, koordinasi jadwal, dan waktu yang diperlukan oleh angkutan umum untuk mengangkut penumpang. Halte dengan rute/trayek yang memiliki headway di bawah 3-5 menit umumnya memiliki daya tampung paling sedikit dua kendaraan, sementara headway antara 510 menit cukup memiliki daya tampung satu kendaraan (Vuchic, 1981:277).

Sedangkan kriteria-kriteria yang digunakan untuk mengetahui kualitas pelayanan Halte BRT BWK I Koridor Mangkang-Penggaron, dinilai melalui mutu pelayanan (SQ-service quality), yang terdiri dari elemen pelayanan kualitatif, seperti kenyamanan (estetika halte), kehandalan, keamanan dan keselamatan, serta kemudahan menggunakan halte BRT. Dalam aspek kehandalan tersebut, halte BRT Trans Semarang menjamin kehandalan operasional, termasuk kelengkapan pengoperasian halte dan petugas operasi halte BRT. Yang menjadi indikator antara lain konsistensi jam pelayanan halte dan jarak antara pintu bus dan halte saat merapat. Sedangkan dalam aspek keamanan dan keselamatan penumpang di halte BRT, sementara dari aspek keamanan yang ditekankan adalah keamanan di dalam halte.

Dari aspek kemudahan, menjamin bahwa penumpang bisa mendapat berbagai kemudahan dalam menikmati layanan halte BRT antara lain kemudahan mendapatkan informasi, kecepatan dalam penjualan tiket, dan kemudahan akses menuju ke halte dan dari halte untuk ketepatan perpindahan rute dan ketepatan pelayanan halte. Kemudahan aksesibilitas dikenal sebagai salah satu faktor yang paling utama yang mempengaruhi penggunaan transportasi. Aksesibilitas transportasi mengacu pada kemampuan penumpang untuk menjangkau fasilitas transportasi, mencakup pemberhentian bus dan/atau stasiun kereta api.

Aspek kenyamanan, menjamin bahwa jasa layanan halte BRT akan dinikmati penumpang secara nyaman. Indikator kenyamanan tersebut, antara lain estetika halte, kebersihan di dalam halte, suhu di dalam halte, penerangan di dalam halte, dan sarana prasarana pendukung halte seperti kursi tunggu penumpang, system ticketing, dan lain-lain. Terakhir adalah ketepatan perpindahan rute.

\section{HASIL ANALISIS}

Untuk mengetahui karakteristik dan sebaran lokasi halte BRT di wilayah studi digunakan data primer dari observasi di lapangan secara langsung. Adapun penilaian masyarakat pengguna didapatkan dengan cara terpilih, yaitu masyarakat yang menggunakan BRT di sekitar BWK I, setelah itu dilakukan pembobotan terhadap jawaban responden. Penilaian terhadap kualitas pelayanan halte BRT BWK I berdasarkan hasil skoring persepsi responden dan penilaian peneliti, termasuk kinerja pelayanan ditentukan berdasarkan aturan dari H.A Sturges. 
TABEL 3

SKORING TERHADAP KRITERIA KUALITAS PELAYANAN HALTE BRT BERDASARKAN PERSEPSI PENGGUNA

\begin{tabular}{|c|c|c|c|c|c|c|c|c|c|c|}
\hline \multirow{2}{*}{ Halte BRT di BWK I } & \multicolumn{8}{|c|}{ Parameter/ Kriteria Pelayanan } & \multirow{2}{*}{$\begin{array}{l}\text { Total } \\
\text { Skor }\end{array}$} & \multirow{2}{*}{$\begin{array}{l}\text { Kualitas } \\
\text { Pelayanan }\end{array}$} \\
\hline & 1 & 2 & 3 & 4 & 5 & 6 & 7 & 8 & & \\
\hline Soegijapranata 1 & 13 & 13 & 14 & 21 & 13 & 16 & 12 & 17 & 119 & kurang \\
\hline Soegijapranata 2 & 13 & 19 & 16 & 23 & 13 & 12 & 13 & 19 & 128 & kurang \\
\hline Pemuda 1 & 16 & 16 & 17 & 22 & 16 & 18 & 13 & 21 & 139 & cukup \\
\hline Pemuda 2 & 13 & 22 & 21 & 23 & 16 & 18 & 16 & 21 & 150 & cukup \\
\hline Pandanaran 1 & 8 & 19 & 19 & 20 & 9 & 8 & 8 & 7 & 98 & kurang \\
\hline Pandanaran 2 & 14 & 16 & 16 & 20 & 9 & 11 & 11 & 10 & 107 & kurang \\
\hline Santika Premier 1 & 14 & 15 & 17 & 19 & 14 & 15 & 17 & 15 & 126 & kurang \\
\hline Santika Premier 2 & 12 & 11 & 15 & 18 & 7 & 12 & 13 & 9 & 97 & kurang \\
\hline Ciputra & 23 & 25 & 28 & 32 & 24 & 28 & 23 & 27 & 210 & baik \\
\hline A.Yani 1 & 12 & 16 & 18 & 21 & 13 & 14 & 10 & 16 & 120 & kurang \\
\hline A.Yani 2 & 11 & 14 & 14 & 21 & 13 & 15 & 12 & 14 & 114 & kurang \\
\hline Katamso & 22 & 25 & 25 & 31 & 22 & 25 & 21 & 26 & 197 & baik \\
\hline Jumlah & 171 & 211 & 220 & 271 & 169 & 192 & 169 & 202 & 1.605 & \\
\hline Kinerja Pelayanan & Kurang & Cukup & Baik & Baik & Kurang & Kurang & Kurang & Kurang & & \\
\hline \multicolumn{11}{|c|}{ Sumber: Hasil analisis, 2010} \\
\hline \multicolumn{11}{|l|}{ Keterangan : } \\
\hline \multicolumn{4}{|c|}{$1:$ Waktu Tunggu BRT } & \multicolumn{5}{|c|}{5 : Kenyamanan Pemanfaatan Halte } & & \\
\hline \multicolumn{4}{|c|}{ 2: Kemudahan Pencapaian Halte } & \multicolumn{5}{|c|}{6 : Kehandalan Pelayanan Halte } & & \\
\hline \multicolumn{4}{|c|}{ 3: Ketepatan Perpindahan Rute } & \multicolumn{5}{|c|}{$\begin{array}{l}7: \text { Jarak antar halte dengan sistem feeder } \\
8: \text { Pelayanan Petugas Halte BRT }\end{array}$} & & \\
\hline
\end{tabular}

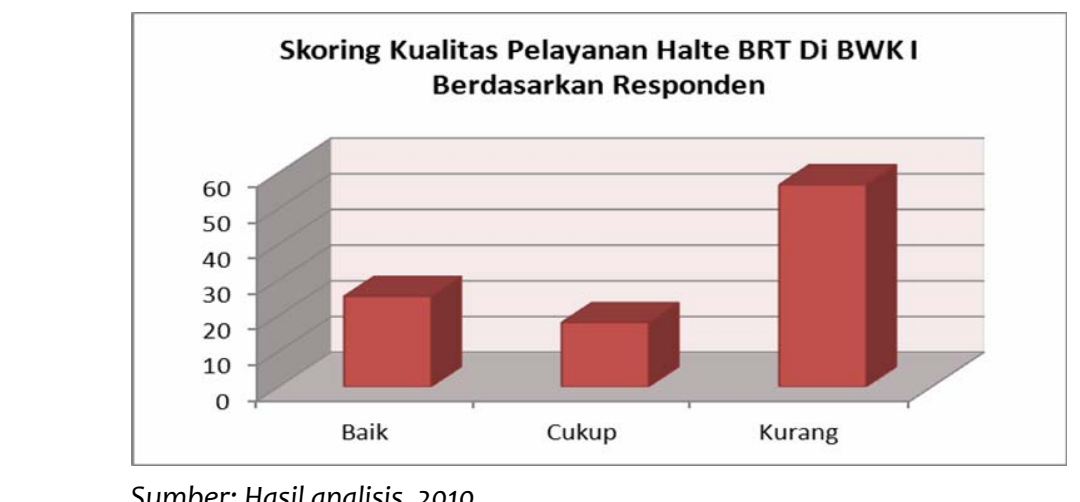

Sumber: Hasil analisis, 2010

GAMBAR 1

SKORING KUALITAS PELAYANAN HALTE BRT BWK I BERDASARKAN RESPONDEN

Secara garis besar bila dilihat secara umum, grafik di atas menunjukkan kualitas pelayanan halte BRT secara keseluruhan di BWK I menurut persepsi reponden, dimana terlihat bahwa halte BRT di BWK I memiliki kualitas pelayanan yang kurang ideal. Bila dibobot secara total untuk kinerja pelayanan halte BRT yang dikatakan kurang sebesar $909(56,61)$ dari total bobot keseluruhan kualitas pelayanan halte BRT menurut persepsi pengguna yaitu 1.605 (100\%), dan halte BRT yang dinilai memiliki kualitas pelayanan halte cukup ideal memiliki bobot 289 (18\%). Sedangkan halte BRT di BWK I yang dinilai masuk dalam kualitas pelayanan baik memiliki bobot nilai 407 (25,35\%). Penilaian perhitungan dan penentuan kinerja pelayanan berdasarkan total skor persepsi pengguna dilakukan dengan menggunakan aturan statistik H.A Sturges. Kualitas 
pelayanan halte BRT dinilai kurang ideal saat ini didukung dengan penilaian responden terhadap kriteria yang mempengaruhi kualitas pelayanan yaitu waktu tunggu, kenyamanan pemanfaatan halte, kehandalan pelayanan halte BRT, jarak halte, dan pelayanan operator jaga halte BRT yang juga masih dinilai kurang ideal oleh responden.

TABEL 4

\section{SKORING TERHADAP KRITERIA KUALITAS PELAYANAN HALTE BRT BERDASARKAN PENELITI}

\begin{tabular}{|c|c|c|c|c|c|c|c|c|c|c|}
\hline \multirow{2}{*}{ Halte BRT di BWK I } & \multicolumn{8}{|c|}{ Parameter/ Kriteria pelayanan } & \multirow{2}{*}{$\begin{array}{l}\text { Total } \\
\text { Skor }\end{array}$} & \multirow{2}{*}{$\begin{array}{l}\text { Kualitas } \\
\text { Pelayanan }\end{array}$} \\
\hline & 1 & 2 & 3 & 4 & 5 & 6 & 7 & 8 & & \\
\hline Soegijapranata 1 & 1 & 2 & 3 & 3 & 1 & 2 & 2 & 1 & 15 & Kurang \\
\hline Soegijapranata 2 & 1 & 2 & 3 & 3 & 2 & 2 & 1 & 1 & 15 & Kurang \\
\hline Pemuda 1 & 2 & 3 & 1 & 3 & 2 & 2 & 1 & 3 & 18 & Cukup \\
\hline Pemuda 2 & 2 & 2 & 2 & 3 & 3 & 2 & 2 & 2 & 18 & Cukup \\
\hline Pandanaran 1 & 2 & 3 & 3 & 2 & 1 & 2 & 1 & 1 & 15 & Kurang \\
\hline Pandanaran 2 & 2 & 3 & 3 & 2 & 2 & 2 & 1 & 1 & 17 & Kurang \\
\hline Santika Premier 1 & 2 & 2 & 2 & 3 & 2 & 2 & 1 & 2 & 16 & Kurang \\
\hline Santika Premier 2 & 2 & 3 & 3 & 1 & 1 & 1 & 3 & 1 & 15 & Kurang \\
\hline Ciputra & 3 & 3 & 3 & 3 & 3 & 2 & 1 & 3 & 21 & Baik \\
\hline A.Yani 1 & 3 & 2 & 3 & 3 & 2 & 1 & 2 & 1 & 17 & Kurang \\
\hline A.Yani 2 & 2 & 2 & 3 & 3 & 2 & 1 & 2 & 2 & 17 & Kurang \\
\hline Katamso & 2 & 3 & 3 & 3 & 3 & 2 & 2 & 3 & 21 & Baik \\
\hline Jumlah & 24 & 30 & 32 & 32 & 24 & 21 & 21 & 21 & 206 & \\
\hline Kualitas Pelayanan & Kurang & Cukup & Baik & Baik & Kurang & Kurang & Kurang & Kurang & & \\
\hline
\end{tabular}

Sumber: hasil analisis, 2010

\section{Keterangan :}

1 : Waktu Tunggu BRT

2 : Kemudahan Pencapaian Halte

3: Ketepatan Perpindahan Rute

4 : Keamanan dan Keselamatan Penggunaan Halte 8 : Pelayanan Petugas Halte BRT
5 : Kenyamanan Pemanfataan Halte

6 : Kehandalan Pelayanan Halte

7 : Jarak antar halte dengan sistem feeder

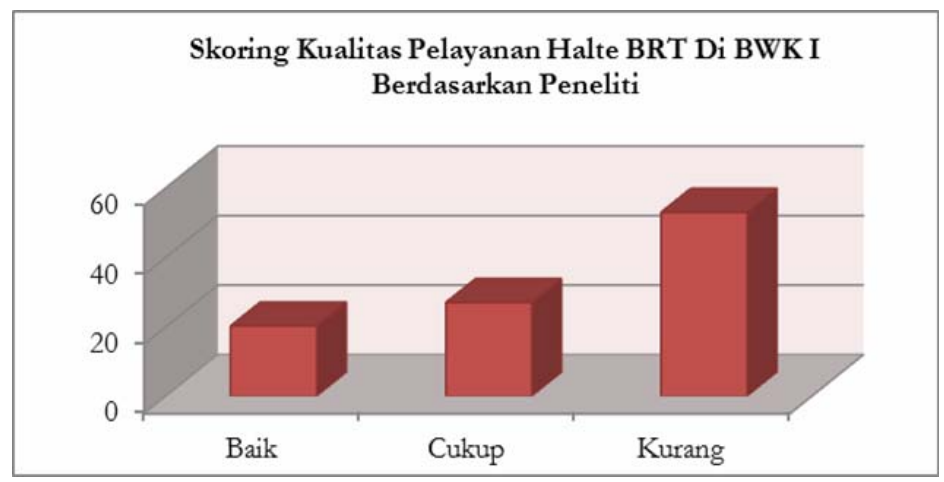

Sumber: Hasil analisis, 2010

GAMBAR 2

SKORING KUALITAS PELAYANAN HALTE BRT BWK I BERDASARKAN PENELITI

Berdasarkan tabel di atas dapat terlihat bahwa kualitas pelayanan halte BRT dinilai kurang ideal, hal ini dikarenakan tidak adanya perhatian dari pihak pengelola terhadap kriteria-kriteria kualitas pelayanan halte BRT yang ideal. Bobot nilai terbesar berdasarkan perhitungan dengan mengadopsi aturan H.A Sturges kualitas pelayanan halte BRT di BWK I yang memiliki kualitas pelayanan kurang ideal menduduki peringkat pertama dengan total bobot $127(61,65 \%)$, halte 
BRT yang memiliki kualitas pelayanan cukup memiliki total bobot 36 (17,47\%), sedangkan halte yang memiliki nilai bobot paling akhir adalah halte dengan kualitas pelayanan baik dengan total bobot $42(20,38 \%)$.

Dari penjelasan tabel dan grafik kualitas pelayanan halte BRT di BWK I berdasarkan penilaian peneliti dapat disimpulkan bahwa kualitas pelayanan yang diberikan di halte BRT BWK I Koridor Mangkang-Penggaron adalah kurang ideal karena dinilai kurangnya perhatian dan pemenuhan pihak pengelola terhadap kriteria-kriteria kualitas pelayanan antara lain waktu tunggu, kenyamanan pemanfaatan halte, kehandalan pelayanan halte BRT, jarak halte, dan pelayanan operator jaga halte BRT yang juga masih dinilai kurang.

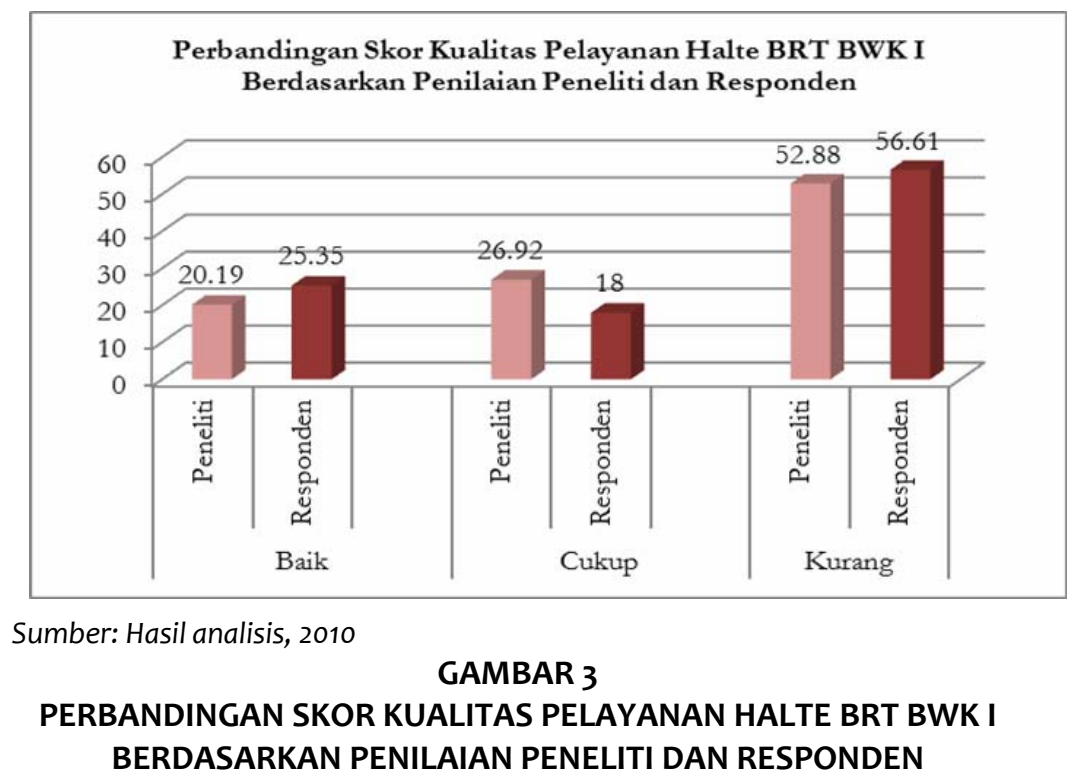

Berdasarkan perbandingan skoring antara penilaian peneliti dan responden dapat ditarik garis kesimpulan dilihat dati total skor bobot dengan aturan H.A Sturges diketahui kualitas pelayanan halte BRT BWK I Koridor Mangkang-Penggaron masuk dalam kualitas pelayanan kurang ideal. Dimana peneliti memiliki bobot terbesar pada kualitas pelayanan kurang ideal sebesar $61,65 \%$, begitu juga dengan penilaian responden dengan bobot terbesar pada kualitas pelayanan kurang ideal dengan total $56,61 \%$. Sehingga penilaian antara responden dan peneliti terhadap kualitas pelayanan halte BRT sama-sama menilai kualitas pelayanan halte BRT di BWK I kurang ideal, begitu juga dalam penilaian terhadap kriteria pelayanannya yang masih dinilai kurang ideal yaitu waktu tunggu, kenyamanan pemanfaatan halte, kehandalan pelayanan halte BRT, jarak halte, dan pelayanan operator jaga halte BRT.

TABEL 5

FASILITAS TAMBAHAN UNTUK HALTE BRT DI BWK I

\begin{tabular}{llll}
\hline No & Fasilitas Halte Tambahan & Jumlah & Persentase (\%) \\
\hline 1 & Telepon Umum & 10 & 10,41 \\
\hline 2 & Papan Informasi & 29 & 30,20 \\
\hline 3 & Pintu Otomatis & 23 & 23,95 \\
\hline 4 & AC/Kipas Angin & 34 & 35,41 \\
\hline & Lainnya & - & - \\
\hline Total & 96 & $100 \%$ \\
\hline
\end{tabular}

Sumber: Hasil analisis, 2010 
Adapun hasil dari analisis ini berupa mutu pelayanan halte BRT di BWK I Koridor MangkangPenggaron. Berdasarkan hasil skoring dengan menggunakan aturan H.A Sturgess dapat diketahui kualitas pelayanan halte BRT. Bentuk pelayanan yang disesuaikan dengan kriteria pelayanan halte BRT dapat dirinci sebagai berikut:

- Penilaian halte BRT ini dilakukan dengan karakteristik responden sebagian besar sebagai pelajar (50\%).

- Berdasarkan penilaian peneliti dan responden dilihat dari total skor bobot dengan aturan H.A Sturges diketahui kualitas pelayanan halte BRT bila dibandingkan antara penilaian peneliti dan penilaian responden masuk dalam kualitas pelayanan kurang ideal. Dimana peneliti memiliki bobot terbesar pada kualitas pelayanan kurang ideal sebesar $61,65 \%$, begitu juga dengan penilaian responden dengan bobot terbesar pada kualitas pelayanan kurang ideal dengan total 56,61\%. Sehingga penilaian antara responden dan peneliti terhadap kualitas pelayanan halte BRT sama-sama menilai kualitas pelayanan halte BRT kurang ideal, begitu juga dalam penilaian terhadap kriteria pelayanannya yang masih dinilai kurang ideal yaitu waktu tunggu, kenyamanan pemanfaatan halte, kehandalan pelayanan halte BRT, jarak halte, dan pelayanan operator jaga halte BRT.

- Kondisi fisik halte BRT juga sudah baik dan sesuai dengan kriteria pelayanan halte, akan tetapi masih ada beberapa halte yang desain fisiknya belum sesuai dengan kriteria desain halte BRT yaitu halte BRT Santika Premier 2.

- Hasil analisis kesenjangan (gap) terhadap kualitas pelayanan menunjukkan bahwa terdapat kesenjangan antara kualitas pelayanan halte BRT yang diberikan operator atau pengelola halte BRT dengan yang diharapkan oleh pengguna BRT. Kesenjangan terjadi hampir pada seluruh halte BRT dalam hal kenyamanan penggunaan halte BRT termasuk sarana dan prasarana penunjang halte BRT.

\section{Evaluasi Kualitas Pelayanan Halte BRT}

Latar belakang dilaksanakannya evaluasi ini karena meskipun masih baru dalam penerapannya, sudah banyak sarana prasarana yang ternyata tidak dapat digunakan. Sisi pemeliharaan masih sangat kurang. Selama ini masih banyak pengguna kendaraan pribadi yang enggan beralih ke Bus Trans Semarang karena fasilitas yang tersedia belum optimal.

TABEL 6

PERBANDINGAN KUALITAS PELAYANAN HALTE BRT DENGAN PELAYANAN IDEAL

\begin{tabular}{|c|c|c|c|}
\hline No & $\begin{array}{l}\text { Kriteria Pelayanan } \\
\text { Halte BRT }\end{array}$ & Penilaian & Kualitas Pelayanan Halte Ideal \\
\hline 1 & $\begin{array}{l}\text { Waktu tunggu BRT } \\
\text { dalam halte }\end{array}$ & Kurang & $\begin{array}{l}\text { Dibutuhkan waktu tunggu yang singkat di dalam halte, } \\
\text { sehingga pengguna layanan BRT tidak mengalami kejenuhan } \\
\text { ketika berada di dalam halte. Dalam hal ini pelayanan yang ideal } \\
\text { harus memperhatikan frekuensi kedatangan BRT yang cepat } \\
\text { terutama pada jam puncak (peak hour). Waktu tunggu } \\
\text { penumpang di halte BRT idealnya disesuaikan dengan jumlah } \\
\text { pengguna, jumlah armada yang dioperasikan, dan tingkat } \\
\text { kedatangan BRT (headway). Standar waktu tunggu yang baik } \\
\text { dan ideal berkisar antara 5-10 menit. }\end{array}$ \\
\hline 2 & $\begin{array}{l}\text { Kemudahan } \\
\text { penggunaan halte }\end{array}$ & cukup & $\begin{array}{l}\text { Kemudahan pencapaian halte yang ideal ditunjjukkan dengan } \\
\text { cara berjalan kaki menuju halte BRT. Panjang jarak tempuh } \\
\text { dengan berjalan kaki dipengaruhi oleh jarak penempatan halte } \\
\text { dari tempat asal melakukan aktivitas pergerakan. Standar yang } \\
\text { disarankan untuk kemudahan pencapaian halte pada jarak yang } \\
\text { ideal antara 300-500 meter. Selain itu kemudahan pengunaan } \\
\text { halte juga dikatakan ideal apabila pengguna bias dengan }\end{array}$ \\
\hline
\end{tabular}




\begin{tabular}{|c|c|c|c|}
\hline No & $\begin{array}{l}\text { Kriteria Pelayanan } \\
\text { Halte BRT }\end{array}$ & Penilaian & Kualitas Pelayanan Halte Ideal \\
\hline & & & $\begin{array}{l}\text { mudah mendapatkan informasi mengenai penggunaan sistem } \\
\text { operasional BRT/ rute pelayanan serta kemudahan dalam } \\
\text { pembelian tiket. }\end{array}$ \\
\hline 3 & $\begin{array}{l}\text { Ketepatan } \\
\text { perpindahan rute }\end{array}$ & baik & $\begin{array}{l}\text { Ketepatan perpindahan rute bisa dikatakan ideal apabila lokasi } \\
\text { penempatan halte terintegrasi dengan moda angkutan umum } \\
\text { lainnya. Sehingga memudahkan pengguna yang ingin pindah } \\
\text { trayek atau dalam melakukan perpindahan moda angkutan } \\
\text { umum atau bus lainnya. }\end{array}$ \\
\hline 4 & $\begin{array}{l}\text { Keamanan dan } \\
\text { Keselamatan } \\
\text { Penggunaan }\end{array}$ & baik & $\begin{array}{l}\text { Halte dikatakan ideal apabila dalam pengoperasiannya mampu } \\
\text { menjamin kepastian keselamatan untuk menaik dan } \\
\text { menurunkan penumpang. Dan aman atau tidak pernah terjadi } \\
\text { tindakan kriminal di dalam halte. }\end{array}$ \\
\hline 5 & $\begin{array}{l}\text { Kenyamanan } \\
\text { pemanfaatan }\end{array}$ & kurang & $\begin{array}{l}\text { Dari kriteria kenyamanan pemanfaatan halte BRT dikatakan } \\
\text { ideal, apabila mampu menjamin bahwa jasa layanan halte BRT } \\
\text { akan dinikmati penumpang secara nyaman. Dilihat dari estetika } \\
\text { halte, kebersihan dalam halte, suhu di dalam halte, penerangan } \\
\text { di dalam halte, dan sarana prasarana pendukung halte seperti } \\
\text { kursi tunggu penumpang, system ticketing, dll. }\end{array}$ \\
\hline 6 & $\begin{array}{l}\text { Kehandalahan } \\
\text { pelayanan }\end{array}$ & kurang & $\begin{array}{l}\text { Halte dikatakan ideal apabila pemenuhan terhadap kriteria ini } \\
\text { mampu menjamin kehandalan operasional, termasuk di } \\
\text { dalamnya kelengkapan dalam pengoperasian halte, petugas } \\
\text { operasi halte BRT, dan adanya konsistensi jam pelayanan halte } \\
\text { pada jam biasa maupun jam sibuk, serta antara pintu bus dan } \\
\text { halte saat merapat. }\end{array}$ \\
\hline 7 & Jarak halte & kurang & $\begin{array}{l}\text { Halte dikatakan memiliki kualitas pelayanan yang ideal/baik } \\
\text { apabila dalam pemenuhan terhadap kriteria jarak antar halte } \\
\text { BRT berkisar antara } 500 \text { meter. }\end{array}$ \\
\hline 8 & $\begin{array}{l}\text { Pelayanan } \\
\text { operator jaga } \\
\text { halte }\end{array}$ & kurang & $\begin{array}{l}\text { Halte dikatakan memberikan pelayanan yang ideal apabila } \\
\text { dalam pengoperasiannya tersedia petugas jaga halte BRT, yang } \\
\text { mengutamakan pelayanan kepada pengguna melalui } \\
\text { keramahan, kerapian, kedisiplinan, serta tanggap terhadap } \\
\text { masalah antrian yang mungkin terjadi di dalam halte. }\end{array}$ \\
\hline
\end{tabular}

Sumber: Hasil analisis, 2010

\section{KESIMPULAN}

Berdasarkan hasil analisis di atas dapat ditarik suatu kesimpulan sebagai berikut:

1. Sebaran dan karakteristik halte BRT dibangun menggunakan median jalan, sehingga dalam peletakan halte tidak menggunakan badan jalan, tetapi untuk parkir bus ketika merapat ke halte mengganggu aktivitas lalu lintas jalan raya sekitar karena tidak adanya bus lane;

2. Hal-hal yang mempengaruhi kondisi pelayanan halte BRT sampai saat ini adalah: jadwal kedatangan bus untuk tiap-tiap halte tidak terjadwal, lokasi halte BRT yang terletak di pinggiran jalan mengakibatkan aktivitas kendaraan yang melaju di depan halte tersebut terganggu, dan adanya kegiatan parkir di pinggir jalan terutama di Jalan Pemuda, Pandanaran, dan sekitar Hotel Santika Premier;

3. Kualitas pelayanan halte berdasarkan hasil penskoran dengan menggunakan aturan H. A Sturges, diketahui bahwa penilaian responden dan peneliti adalah sama. Dimana peneliti memiliki skor terbesar pada kualitas pelayanan kurang ideal sebesar $61,65 \%$, begitu juga dengan penilaian responden dengan skor terbesar pada kualitas pelayanan kurang ideal dengan total $56,61 \%$. Kualitas pelayanan halte BRT kurang ideal, sedangkan untuk kriteria 
kemudahan pencapaian halte dinilai cukup karena mudah dijangkau dengan berjalan kaki atau menggunakan AUP lain, dan kriteria yang dinilai baik adalah ketepatan perpindahan rute serta kriteria keamanan dan keselamatan penggunaan halte.

4. Menurut pendapat responden, fasilitas tambahan yang dibutuhkan di dalam pelayanan yang diberikan halte BRT BWK I berupa AC/kipas angin sebanyak 35,41\%, papan informasi dan papan display jadwal BRT 30,20\%, pintu otomatis $23,95 \%$, serta fasilitas berupa telepon umum sebanyak $10,41 \%$.

5. Berdasarkan hasil evaluasi ini dapat diketahui meskipun masih baru dalam penerapannya, sudah banyak sarana prasarana yang ternyata tidak dapat digunakan. Sisi pemeliharaan masih sangat kurang. Beberapa temuan hasil evaluasi yang diperoleh yaitu pada Trans Semarang BRT yang sedang beroperasi masih kurang bila dibandingkan kondisi ideal, maksudnya karena jalur bus jadi satu dengan kendaraan lainnya maka ketika bus merapat ke halte untuk menaik-turunkan penumpang jaraknya masih lumayan jauh $\pm 30 \mathrm{~cm}$, dan kelengkapan fasilitas halte masih kurang keberadaannya.

\section{DAFTAR PUSTAKA}

Abadi, Tulus. 2005. "Fakta Buruknya Transportasi Publik di Indonesia." Wacana Jurnal Ilmu Sosial Transformatif. Edisi 22 tahun VI 2005.

Bruton, 1981. Introduction to Transportation Planning. Hutchinson Technical Education.

Draft Pedoman Teknis Angkutan Bus Kota Dengan Sistem Jalur Khusus Bus (JKB / Busway, Direktorat Bina Sistem Transportasi Perkotaan Ditjen Perhubungan Darat 2006.

Design Guidelines For Busway Transit. 1993. Overseas Centre, Transport Research Laboratory. Gressando, Julian. 2003. Dasar-Dasar Rekayasa Transportasi Jilid 2. Jakarta: Erlangga.

Istianto, Bambang. 2009. Manajemen Pemerintahan Dalam Perspektif Pelayanan Publik. Jakarta: Mitra Wacana Media-STIAMI.

Moleong, Lexy J. 2000. Metodologi Penelitian Kualitatif. Bandung: PT. Remaja Rosdakarya Offset.

Miro, Fidel. 1997. Sistem Transportasi Kota. Bandung: Tarsito.

Morlok, Edward K. 1994. Teknik dan Perencanaan Transportasi. Jakarta: Erlangga.

Nasution, M. Nur. 2004. Manajemen Transportasi. Edisi Kedua. Jakarta: Ghalia Indonesia.

Nazir, Moh. 2003. Metode Penelitian. Jakarta: Ghalia Indonesia.

Parasuraman, A. Valerie A. Zeithmal, dkk. 1985. "A Conceptual Model of Service Quality and its Implications for Future Research.” Journal of Marketing. Vol 49 (Fall 1985), 41-50.

Riduwan. 2009. Skala Pengukuran Variabel-Variabel Penelitian. Bandung: Alfabeta.

Salim, Abbas. 2002. Manajemen Transportasi. Jakarta: PT. Raja Grafindo Persada.

Setijowarno, Djoko. 2003. Dinamika Transportasi. Semarang: Universitas Katholik Soegijapranata.

2005. Kebijakan Transportasi: Kenyataan dan Harapan. Semarang: Universitas Katholik Soegijapranata

Shen, L. David, Hesham Elbadrawi, Fang Zhao, Diana Ospina, At-Grade Busway Planning Guide (Miami: Florida International University, Desember 1998).

Suryokusumo, Anggoro-Ferry. 2008. Pelayanan Publik dan Pengelolaan Infrastruktur Perkotaan. Yogyakarta: Sinergi Publishing.

Tamin, Ofyar. 2000. Perencanaan dan Pemodelan Transportasi. Edisi Kedua. Bandung: ITB.

Vuchic. 1981. Urban Public Transportation, System and Technology. New Jersey, USA: Prentice Hall. 